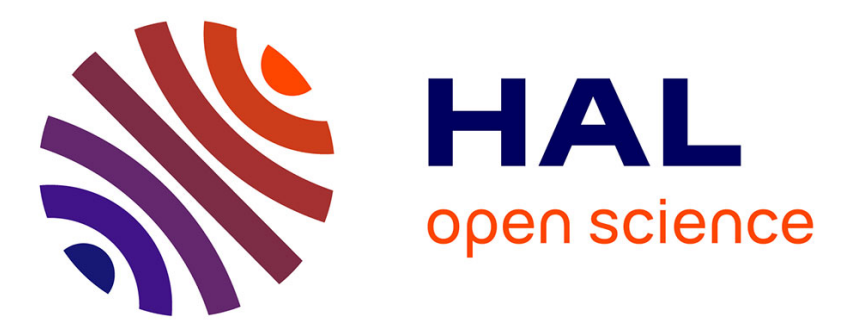

\title{
Working Time, Industrial Relations and the Employment Relationship
}

Jill Rubery, Kevin Ward, Damian Grimshaw, Huw Beynon

\section{To cite this version:}

Jill Rubery, Kevin Ward, Damian Grimshaw, Huw Beynon. Working Time, Industrial Relations and the Employment Relationship. Time \& Society, 2005, 14 (1), pp.89-111. 10.1177/0961463X05050300 . hal-00570991

\section{HAL Id: hal-00570991 \\ https://hal.science/hal-00570991}

Submitted on 1 Mar 2011

HAL is a multi-disciplinary open access archive for the deposit and dissemination of scientific research documents, whether they are published or not. The documents may come from teaching and research institutions in France or abroad, or from public or private research centers.
L'archive ouverte pluridisciplinaire HAL, est destinée au dépôt et à la diffusion de documents scientifiques de niveau recherche, publiés ou non, émanant des établissements d'enseignement et de recherche français ou étrangers, des laboratoires publics ou privés. 


\title{
Working Time, Industrial Relations and the Employment Relationship
}

\author{
Jill Rubery, Kevin Ward, Damian Grimshaw \\ and Huw Beynon
}

\begin{abstract}
This article explores the erosion of the standard working-time model associated with the UK's voluntarist system of industrial relations, and argues that its renegotiation is likely to be a critical factor in shaping the employment relationship of the future. As numerous studies over the last two decades have revealed, organizations have increasingly seen 'time' as a variable that can be manipulated to increase productivity or expand service provision, through making workers work harder, longer or according to management demands. These studies have also drawn our attention to the wider consequences of the increasing demands that organizations place on their employees in the name of 'flexibility', impacting both on what workers do while at work and how they organize and plan the other aspects of their lives. This article brings together two literatures, one on time and the other on industrial relations, and suggests that new working-time arrangements are changing the wage-effort bargain and blurring the previously clearly demarcated boundary between work and non-work time. Drawing on qualitative fieldwork in six large UK-based organizations, we argue that there is evidence of a move towards a new 'temporality' based on an employer-led model of working time, which differs significantly from both the traditional UK system of working-time regulation and that found in Continental Europe. KEY WORDS • employment relationship $\bullet$ intensification of work $\bullet$ non-working time $\bullet$ organizational change $\bullet$ working time
\end{abstract}

\section{Introduction}

It is hardly possible to pick up a newspaper or to turn on the radio without hearing something about the relationship between time and work: from the growth

Time \& Society copyright (C) 2005 SAGE (London, Thousand Oaks, CA and New Delhi) VOL. 14 No. 1 (2005), pp. 89-111 0961-463X DOI: 10.1177/0961463X05050300

www.sagepublications.com 
in 24-hour opening among food retailers to the expansion of part-time work, from the withdrawal of 'bonuses' for unsocial working to the pronouncements of the need to balance 'work' and 'life'. All these issues have risen up the UK political and the policy agenda in the last decade as a consequence of the time demands that organizations increasingly appear to place on those who work for them. While there is no consensus on the extent of the changes and their implications for those who experience them, there is some agreement that the organization and regulation of working time in industrialized economies has changed in quite far-reaching ways (OECD, 1995; Bosch, Dawkins and Michon, 1994; Bosch, 1999; Boulin and Hoffman, 1999; Casey et al., 1997; Hochschild, 1997; Lehndorff, 1998; Rubery, 1998a; Harkness, 1999; Harvey, 1999; Green, 2001; Kalleberg and Epstein, 2001; Tietze and Musson, 2002). This work has also increasingly pointed to how changes in working-time arrangements have potentially wider implications than 'just' the restructuring of the hours of work. Negotiations over 'time' and its meaning were at the heart of the standard employment relationship, protected by trade unionism and collective bargaining arrangements (Thompson, 1967). Under the industrial order 'time spent at work was experienced as time allocated to the employer in exchange for a wage, while time spent in the private sphere was experienced as "free" (Everingham, 2002: 338). The current renegotiation of 'time' has the potential to bring about major changes in the organization of the wider society and in the nature of the employment relationship, with some going as far to claim that what we have witnessed in recent years across the most industrialized nations is the end of social time (Probert, 1997) and 'the end of any distinction between social and unsociable hours of work' (Everingham, 2002: 346). In this vein, Harvey (1999) (drawing on Thompson's earlier work) has referred to the idea of 'changing temporalities' (pp. 22-3; see also Glucksmann, 1998), where 'the restructuring of employment relations can be viewed as a restructuring of the temporalities of work'.

This article addresses this argument by seeking to understand the rationales behind, and the implications of, the ways in which some large organizations are changing how they allocate and organize work over the day, week, month and even, in some cases, the year. In the second section of this article we set out three modes, or 'types' of working-time organization that have emerged in industrialized economies, as a means of examining the direction and form of recent changes. The third section outlines the organizations in which we conducted fieldwork and the methods we used. In the fourth section we draw upon empirical material to examine the many ways organizations are demanding that workers work longer, harder, and more flexibly across time and consider what the consequences are for the work experiences of different occupational groups. Finally, we consider the factors that have influenced the timing of these changes and reflect on their likely implications for the future of the employment relationship. 


\section{Three Modes of Organizing Working Time}

It is clear that 'time' played a central role in the constitution of the employment relationship that emerged as part of mass industrialization, in which temporal boundaries between 'public' and 'private' life were created as part of the 'social compromise. . . in the political sphere between organized labour and capital' (Everingham, 2002: 339). This relationship differentiated between 'paid time', for which employees received financial compensation - the wage - and 'free' time, available to use at one's discretion. ${ }^{1}$ As could be anticipated, this 'compromise' was reached in different parts of the world at different times - as a model it evolved unevenly - and the terms of the exchange varied according to regulatory, institutional and customary norms and practices.

From a 'time' perspective though what is important is how the standard employment relationship placed time-related limits on: (a) the relationship between the wage (or the total reward package) that workers received, and the effort or labour required in order for them to 'earn' the wage and other rewards; and (b) the share of the day, week or year that was under the control of the employer. By establishing standard working days, defined by hours not output, employers could only set tasks that could be performed in the allotted time. Moreover, by establishing the principle of continuous working days, based around full-time employment, employers were constrained in their use of working-time schedules to maximize work intensity. The divide between standard hours and non-standard hours further constrained employers as employees at a minimum needed to be compensated by extra payments to give up 'free' time, particularly if the hours worked were at times regarded by wider society as being particularly unsocial. Reference in labour law to working time 'limits the employer's hold on the worker's life' (Supiot, 2001: 60), and distinguishes an employment relationship from a slave or ownership contract. Yet the division may be clearer under some employment relationships than under others. According to Supiot, and as we have already begun to suggest, one of the features of the industrial system was to make a clear distinction between what he calls 'subordination time' and 'free time' (p. 64; see also Adam, 1990; Everingham, 2002). Those conditions that tend to sharpen this divide include:

1. Pay and rewards linked to time;

2. Work for the employer outside standard or contractual hours done only on a voluntary basis and with advance warning;

3. Work space and personal space clearly separated (as in the 'home' as private and the 'workplace' as public);

4. Non-standard work time clearly identified through wage enhancements (such as high hourly rates for Saturday and Sunday working) and;

5. Regular scheduling of working hours to facilitate the planning of private 
activities, such as performing domestic duties, or organizing leisure activities, without risk of disruption.

Despite the long-term apparent consensus to respect the time-based limits of the standard employment relationship, the wage-effort bargain and the division between work and non-work time are inherently contested aspects of the employment relationship. Employers or managers tend, ceteris paribus, to seek to maximize effort relative to wage costs and to extend their control over the deployment of labour time. So, the growth of what has been termed in the media the '24/7 economy' or of 'flexi-time' arrangements constitute efforts by employers to extend the times of the day, week and year when they can ask staff to work, and to use this new 'flexibility' to schedule the work when for them it is most productive. As a result of this expansion of when workers might work, new fault-lines have been opened up around the balancing of non-paid and paid work. For trade unions the control of the time dimensions of the employment relationship is recognized to be critical, both for the well-being of their members and for establishing bargaining leverage (Hinrichs et al., 1991).

Table 1 sets out three alternative scenarios for how the time within the employment relationship may be organized and regulated. The first scenario or mode - represents a pure employer-led model, unconstrained by state regulation or trade unions. As such, it represents perhaps the conditions which employers may be striving towards and which employees are seeking to protect themselves against, although of course this model may never be realized. The consequences for the organizing of the time worked by workers is the requirement to be completely flexible, such as in the case of 'zero-hour' contracts, when work is scheduled according to the needs of employers, and without any attention to the needs, preferences or desires of workers. Two different modes of flexibility may be sought by employers: the first involves the scheduling of work across the available 24/7 and annual time cycles to match available labour to demand, thereby reducing overhead costs and maximizing work intensity, particularly if labour can be purchased in small blocks of discontinuous time. This fragmented system leads to intensive effort in comparison to the 'extensive effort' (Green, 2001) in jobs where workers are required to work until tasks are completed. Moreover, employers may be able to extract even more extensive effort if presence in the workplace is taken as an indicator of general 'commitment' (Simpson, 1997). The second method of employer flexibility is to set the job tasks to be performed and the associated reward package independently of specified work time - a results-based employment relationship in contrast to the time-dependent, means-based relationship (Supiot, 2001: 83). In this case the time at work becomes an output of the employment relationship dependent, inter alia, on the workload, on responsibilities for work co-ordination and on the individual competence or efficiency of the employee. 
TABLE 1

Three modes of organizing working time

\begin{tabular}{|c|c|c|c|}
\hline $\begin{array}{l}\text { Time dimensions } \\
\text { to the employment } \\
\text { relationship }\end{array}$ & $\begin{array}{l}\text { Employer-led } \\
\text { model }\end{array}$ & $\begin{array}{l}\text { European } \\
\text { industrial } \\
\text { relations model }\end{array}$ & $\begin{array}{l}\text { Traditional UK } \\
\text { industrial relations } \\
\text { model }\end{array}$ \\
\hline $\begin{array}{l}\text { Time and the } \\
\text { wage-effort } \\
\text { relationship }\end{array}$ & $\begin{array}{l}\text { Tailor hours to } \\
\text { demand to maximize } \\
\text { productive effort; or } \\
\text { delink wages and } \\
\text { hours to maximize } \\
\text { total labour provided. }\end{array}$ & $\begin{array}{l}\text { Control standard } \\
\text { hours and overtime } \\
\text { hours to limit total } \\
\text { amount of effort } \\
\text { provided. Part-time } \\
\text { work resisted as } \\
\text { threat to standard } \\
\text { contract. }\end{array}$ & $\begin{array}{l}\text { Control effort levels } \\
\text { through job } \\
\text { demarcation and } \\
\text { protection of } \\
\text { standard hours to } \\
\text { maximize total hours } \\
\text { of paid labour; } \\
\text { promote overtime at } \\
\text { premium rates. } \\
\text { Permissive attitude } \\
\text { towards part-time } \\
\text { work. }\end{array}$ \\
\hline $\begin{array}{l}\text { Work/non- } \\
\text { work time } \\
\text { boundaries }\end{array}$ & $\begin{array}{l}\text { Deploy labour as and } \\
\text { when required over } \\
\text { the } 24 \text {-hour day, } \\
\text { week, year. }\end{array}$ & $\begin{array}{l}\text { Voluntary and } \\
\text { legal protection of } \\
\text { standard hours, } \\
\text { premia rates, } \\
\text { holiday entitlement } \\
\text { and restrictions on } \\
\text { total hours and days } \\
\text { of work, such as } \\
\text { policy of free } \\
\text { Sunday. }\end{array}$ & $\begin{array}{l}\text { Voluntary protection } \\
\text { of standard hours, } \\
\text { premia rates, } \\
\text { holiday entitlement } \\
\text { but extra hours and } \\
\text { unsocial hours } \\
\text { accepted at extra } \\
\text { remuneration. }\end{array}$ \\
\hline
\end{tabular}

The second and third columns represent alternative modes of regulating the time dimension of the employment relationship, in which the interests of labour are protected in different ways and to different extents (Donaldson, 1996). The second column represents the continental European approach, where many European trade union movements have sought to control maximum working hours and have placed great store by their rights to 'free time' (Supiot, 2001). For example, one of the major achievements of German trade unions in the 1960s and 1970s was to introduce the 'free Saturday' where through collective agreements they were able to limit Saturday working, in addition to the free Sunday, guaranteed by legal regulation. This 'time' was then available to workers to attend to other aspects of their lives. Most European countries set maximum working hours and maximum overtime hours and expect extra hours to be taken as time off in lieu rather than as paid working hours (Anxo and O'Reilly, 2000). Many of the limitations on working hours are reinforced by both collective and legal regulation. 
The third column of Table 1 presents the traditional way in which the time that staff work in the UK has been regulated. This has involved establishing and protecting the notion of 'standard working hours', notionally for most workers, ' $9-5$ ', but not the regulation of total working hours. Provided the extra hours were rewarded at appropriate rates, in the form of higher hourly rates for evening or weekend work, British trade unions have by and large welcomed overtime opportunities. For some, lower-paid workers, working overtime meant earning a living wage. As a result the UK industrial relations system has for a number of years consisted of the opportunity for workers to work extra paid hours, in the form of overtime or extra shifts, sometimes as a means of making up the total wage and compensating for the relatively low hourly rates. The role of campaigns to reduce standard working hours in the UK has thus been ambiguous, with employers interpreting the claims as a wage-bargaining strategy rather than a genuine campaign to reduce actual hours of work. As such, employers in the past have tied any reduction in standard hours to efforts to increase productivity within standard hours (White, 1980; Blyton, 1992; 1995).

The strategy on part-time work also varies between the continental and the British modes of working-time regulation. Many European trade union movements have historically been very wary of the development of part-time work, identifying it as a threat to the standard employment contract (Daune-Richard, 1998) by encouraging fragmentation. However, where part-time work has been developed on a large scale it has been integrated into the system of legal and collective regulation. A good example of this is in the Netherlands, where part-time work does not necessarily equate with poorer pay and terms and conditions. British trade unions have perhaps been less sensitive to possible threats to their ability to regulate the employment relationship arising from the development of part-time work (Daune-Richard, 1998). However, this neglect of the part-time issue led to the development, in the highly deregulated labour market of the 1980s, of highly marginalized forms of part-time working within the UK (Maier, 1994; O'Reilly and Fagan, 1998; Rubery, 1998b). Under the rising awareness of gender equality issues, interest in regulating part-time work and conditions has grown, spurred on by developments in EU-wide regulations designed to gain the support of continental European unions for the promotion of flexible working. However, EU regulations have not addressed the development of more fragmented and variable scheduling of part-time work and instead have concentrated on ensuring that part-timers receive the same terms and conditions as full-time workers. This approach allows part-time work to set new norms for flexible deployment and scheduling that may have spill-over effects on some full-time workers, as we explore later (Rubery, 1998b).

The consequences of each of the regulatory models for actual working time, pay and employment contracts are outlined in the Table 2 . There are some clear 
TABLE 2

The consequence of the three modes of working time

\begin{tabular}{|c|c|c|c|}
\hline $\begin{array}{l}\text { Time dimensions } \\
\text { to the employment } \\
\text { relationship }\end{array}$ & $\begin{array}{l}\text { Employer-led } \\
\text { model }\end{array}$ & $\begin{array}{l}\text { European } \\
\text { industrial } \\
\text { relations model }\end{array}$ & $\begin{array}{l}\text { Traditional UK } \\
\text { industrial relations } \\
\text { model }\end{array}$ \\
\hline \multicolumn{4}{|l|}{$\begin{array}{l}\text { Employment } \\
\text { outcomes }\end{array}$} \\
\hline Hours & $\begin{array}{l}\text { Long hours for } \\
\text { salaried full-timers } \\
\text { combined with short } \\
\text { hours contracts/ } \\
\text { variable shifts/split } \\
\text { shifts and so on. }\end{array}$ & $\begin{array}{l}\text { Standard hours for } \\
\text { full-timers; } \\
\text { overtime hours } \\
\text { taken mainly as } \\
\text { time off in lieu. } \\
\text { Part-time work use } \\
\text { limited and/or } \\
\text { subject to } \\
\text { restrictions. }\end{array}$ & $\begin{array}{l}\text { Long hours for full- } \\
\text { timers based on paid } \\
\text { overtime plus short } \\
\text { hours contracts. } \\
\text { Limited use of time } \\
\text { off in lieu. }\end{array}$ \\
\hline Pay & $\begin{array}{l}\text { Minimum use of } \\
\text { paid overtime and } \\
\text { unsocial hours and } \\
\text { overtime premia. } \\
\text { Limited employment } \\
\text { related benefits. }\end{array}$ & $\begin{array}{l}\text { Low level of paid } \\
\text { overtime but } \\
\text { unsocial hours and } \\
\text { overtime premia } \\
\text { maintained. } \\
\text { High level of } \\
\text { employment-related } \\
\text { benefits often } \\
\text { backed by legal } \\
\text { rights/state provision. }\end{array}$ & $\begin{array}{l}\text { High level of paid } \\
\text { overtime, high level } \\
\text { of unsocial hours } \\
\text { and overtime premia. } \\
\text { Employment-related } \\
\text { benefits provided } \\
\text { selectively } \\
\text { dependent upon } \\
\text { employer and } \\
\text { contract status. }\end{array}$ \\
\hline Contracts & $\begin{array}{l}\text { High use of } \\
\text { temporary contracts, } \\
\text { short part-time work } \\
\text { to reduce overhead } \\
\text { costs/maximize } \\
\text { productivity. }\end{array}$ & $\begin{array}{l}\text { Use of open-ended } \\
\text { standard employment } \\
\text { contracts. Part-time } \\
\text { work contracts } \\
\text { subject to restrictions } \\
\text { or protection. }\end{array}$ & $\begin{array}{l}\text { Use of open-ended } \\
\text { standard } \\
\text { employment } \\
\text { contracts but } \\
\text { also use of part-time } \\
\text { contracts on a more } \\
\text { variable basis. }\end{array}$ \\
\hline
\end{tabular}

similarities between the employer-led and the traditional UK regulatory models. Both generate long working hours, a high frequency of unsocial hours working and high part-time use. There are also notable differences, in particular with respect to the incidence of paid overtime, the protection of the notion of 'standard hours' working and the protection of employer-based benefits covering non-work time. It is in this context of both similarities and differences that we can explore the extent to which UK employers are changing the ways in which they regulate 'time', and all that this implies for workers. For as firms move 
away from the traditional UK regulatory model towards an employer-led model - tempered to some extent by EU regulations influenced by the continental European model - we may be witnessing the emergence of a new 'temporality', and as part of it new time rhythms in wage work and beyond. To assess the ways in which these changes are actually being introduced, and the consequences for the temporal ordering of everyday work life, we turn in the next section to our case-study organisations.

\section{A Study of Working-time Change through Case Studies}

\section{Research rationale}

While the amount of research in the UK on the ways in which working time is organized and regulated has grown in line with the expansion of time-specific employment contracts, there is not yet any consensus over the extent of the changes in the mode of temporal regulation. Some research has emphasized the continuing influence of sector level bargaining and traditions on working-time arrangements (Arrowsmith and Sisson, 1999), while Gall (1996) has questioned whether annualized hours schemes are actually that common across UK organizations. This contrasts with analyses that stress the development and normalization of 'flexible working' arrangements (Neathey and Hurstfield, 1996; Casey et al., 1997), the decline of collective regulation of working time (Blyton, 1994; 1995; Beatson, 1995) and the increasing encroachment of work time on personal time (Lewis, 1997; Clark-Campbell, 2000; Fagan, 2001). While there is some disagreement over the extent to which 'new', more flexible arrangements are really transforming the standard employment relationship, the evidence on the amount of time UK workers spend working is more clear-cut: national statistics indicate a trend towards more men and women working long hours (Harkness, 1999; Fagan, 2001; Green, 2001). In itself this evidence could support either the continuation of the traditional UK model or the rise of employer-led working time (Blyton, 1994; Rubery et al., 1998; Kodz et al., 1998; Fagan, 2001).

One way of understanding the context and the meaning of the changes to working-time arrangements is through extensive qualitative research at different workplaces. Case studies of this kind have highlighted the impact of changes in working time - generally in the name of 'flexibility' - upon power relations, on the ways in which 'work' and 'free' time bleed into one another, and on the ways in which the employment relationship is institutionalized (Rubery and Horrell, 1993; Heyes, 1997; Harvey, 1999). However, these studies have often relied on evidence from a single case (Bacon and Storey, 1996; Heyes, 1997), a single sector, usually in manufacturing or construction (Blyton, 1995; Harvey, 
1999) or have been selected as cases precisely because something interesting appeared to be happening around working time (Curson, 1986; Rubery and Horrell, 1993). As such, this article does something different: it draws on material generated through semi-structured interviews at organizations not chosen as cases on the basis that they were in the throes of introducing changes in the organization of working time.

\section{The case-study organizations: an introduction}

The six large service sector organizations - two in the public and four in the private sector - were visited during 1998 and 1999 (see Appendix) and each, as might be expected, had a history of the collective regulation of working time. Our case-study organizations were chosen for analysis as part of a larger project concerned with the overall management of employment change (Beynon et al., 2002). Although we were aware that the reorganizing of when staff worked was likely to be an issue for some workers in some of the organizations, we were surprised at what we found when we visited workplaces. Managers and workers both wanted to talk about 'working time': at some sites it was the issue. Even at those workplaces where the organization of working time had been largely untouched for a number of decades, we were left in no doubt by managers that change was around the corner, that workers would be required to change when they worked and that they would not receive the same rewards they might traditionally have expected to have received for working evenings of weekend, or at different times from one week to the next.

The six organizations in our study consisted of two large public sector organizations - a city council (Councilco) and a large hospital trust (Healthco) and four private sector organizations - a large food supermarket chain (Retailco), a medium-sized bank (Bankco), a large telecommunications company (Telecomco) and a medium-sized media company (Mediaco). The key features of the six organizations and the workplaces studied within these organizations are outlined in the Appendix at the end of this article. Information on changes in working-time arrangements was obtained through semi-structured interviews with managers (both head office or regional managers in the case of national organizations and line managers of the workplaces studied) and through shorter semi-structured interviews with employees who performed the range of tasks carried out at the workplaces. Overall we held 41 interviews with higher-level managers and 226 interviews with lower managerial/supervisory and non-managerial employees. We also interviewed the key trade union officials responsible for collective negotiations at each of the organizations. These three sources of information, combined with the documentary material provided by the organizations and articles identified in the press, provided us with an overlapping series of perspectives on how working time was organized 
at each workplace, and across each of the organizations more generally. We now turn to explore our two main themes: the change to the time structuring of the wage-effort bargain and the blurring of 'work' and 'free' time at each organization.

\section{Changes to Working Time}

In this section we present and discuss our findings from our organization studies. In the first part we document how in two ways employers were using 'time' as a means of changing the wage-effort relationship and consider the implications of these changes for the experience of work and time. In particular, we explore how changes in time resulted in intensification for some groups of workers, while for others time was extended and employers constructed variable time inputs that were perceived as providing a 'solution' to managing increased tasks and responsibilities at work. From our conversations with managers and workers it was clear that the implications of these changes did not stop when workers left their place of work. In the second part of this section we turn to the different ways in which organizations were changing what was meant by 'standard hours', and consider what workers felt was a clear - and financially unrewarded - intrusion into what had previously been their 'free' time.

\section{Time and the restructuring of the wage-effort bargain}

At each workplace we visited, managers and workers were clear: working-time policies had been used to restructure the wage-effort relationship in two distinct but related ways. First, for those on time-related contracts staff had to do more during their hours of work. The tempo of work was increasing as the mix of 'active' and 'non-active' periods was adjusted so that many of the workers found themselves working 'flat out' for many of their hours of work. Second, those on 'results-based' contracts, such as those on supervisory or managerial grades, were being required to work both harder and longer, to stay at work, or work from home, to get the job done. Moreover, more staff, at relatively low levels of the organizational hierarchy, were being expected to 'go the extra mile' to provide additional time input as part of their expected normal duties. In both cases what we found was that time was being used as a means of securing greater effort for the same reward whether extracted through an intensification of work or a prolongation of working hours.

We found five different strategies being adopted by the organizations at the workplaces we visited that used working time to increase the intensity of work: 
1. A greater use of 'flexible scheduling' for both full- and part-timers to target the hours worked when demand for services was predicted to be greatest (for example, at Councilco, managers formed a number of home care worker teams that had to work flexible schedules to meet the needs of those recently released from hospital, with no regard to the preferences of workers to work the same hours each week in order that they could plan non-work activities);

2. The expectation that staff would take overtime as time off in lieu in the context of declining staff levels relative to demand (for example, journalists at Mediaco were no longer paid for the overtime they worked but instead had to take time off in lieu at 'slack times', even though the reduction of staff numbers made this very difficult to do in practice);

3. The cutting of the 'core hours' for part-timers (for example, Telecomco reduced part-timers' hours from five to four hours a day to reduce paid breaks and Councilco reduced the core hours of school dinner staff, who therefore often worked only for two or three hours over lunchtime) and the reduction of break times or the complete elimination of breaks, as part of a shortening of the number of hours staff worked on any one day (for example, Retailco eliminated paid breaks);

4. The extension of 'operating hours' - that is when workplaces were staffed and workers were expected to be able to work - without an increase in staff numbers (for example at Mediaco's print works the operating hours were extended and the number of men per shift were reduced, with a rotating shift used to eliminate paid overtime); and

5. The linking of time schedules - that is when staff worked - to tighter job specifications, so that what individual staff were responsible for doing on a particular day or during a shift was transparent.

These different strategies had a radical impact on the traditional wage-effort relationship across the six organizations. The first form of change involved the intensification of work for those on time-related contracts. Our fieldwork at Councilco was revealing. We spoke to the predominantly female home-care workers and school catering workers who were paid by the hour and who had experienced a change in when they worked. Not only was the 'porosity', or what Supiot (2001) terms the paid 'on-the-job inactivity' reduced, but paid overtime, which some workers used to compensate for the relatively low hourly rate, was effectively abolished. The reasons that managers gave for this rescheduling of hours was that it was necessary in order to match the new requirements of the job, where workers were being expected to take on extra tasks and to meet much clearer indicators of performance in the context of a reduction in staff numbers. As one worker explained to us:

It's run more like a business. . . whereas before you'd go in and it was like a more friendly basis. You'd go in and you'd do what was required of you and then [the 
patients] want the company, cup of tea, sit down and have a chat whereas you can't do that now because time's money, you can't do that. (Female part-time No. 4, Councilco)

In addition, while we were carrying out our research, Councilco invoked for the first time a clause in the employment contracts of home-care workers that had been introduced in 1984. All home care workers were required to be available to work any time from $8 \mathrm{am}$ to $8 \mathrm{pm}$, as part of 'standard hours'. What this meant for the workers we interviewed, many of whom had chosen the job precisely because the hours of work fitted around their other activities, such as dropping off and picking up children, or when a partner or spouse worked, was a need to reassess how they organized their lives. The effect of these changes at work was to compromise the often carefully constructed temporal order of workers, who had to respond to changes at work by rearranging the timing of other aspects of theirs and their dependants' lives.

The different working-time strategies generated a second form of change to the wage-effort relation - the development of 'results-based' contracts where hours varied according to the task assigned rather than according to standard working weeks. We found evidence that organizations were reclassifying jobs as either 'supervisory' or 'managerial' as a means of moving staff off 'timebased' contracts. This had the effect in our case-study organizations of increasing the proportion of the workforces who could be expected to work longer hours or to work at unsocial times of the day, night or week and not expect to receive any paid overtime. Increased hours for managers or supervisors were often associated with the extension of operating hours, as in banks extending the hours over which they will deal with customer queries, and/or with the reduction in staff numbers, so that managers had to work to ensure that targets and outputs, on which they would be judged, were reached. For example, Retailco managers had to be prepared to work as and when required outside of their contracted hours:

We [lower-level managers] do five days a week [but] some weeks we work six days a week. . . I don't always get a dinner hour, I don't always get out on time ... sometimes on the shop floor we could do a 13/14 hour-day. (Female full-time No. 1, Retailco)

Even relatively low-level managers found themselves under increased pressure to work more hours, either longer days or on days when their time was normally 'free'. At Healthco, porter managers were in principle given contracts for 37 hours a week but received no extra pay for the regular overtime they worked. Aside from the implications of this extra working for their personal lives, this also meant that often the porter managers' hourly rates were lower than those of their juniors. At Councilco we found relatively low-paid school meals supervisors putting in extra, unpaid overtime hours each week. When questioned 
about why they were working extra hours, in the context of what appeared to be a devaluing of many of the things that they used to do, they responded in a number of ways. They felt a loyalty to the pupils and the other staff they worked with, and also, often a more ideological or philosophical commitment to some sort of public service ethos. In principle these 'extra hours' could be taken as time off in lieu, but, perhaps because of the realities of the conditions under which most staff worked, most of the time this right was not exercised:

It's changed because in September we started on breakfasts so my hours start now at 7.15am officially till quarter to three because that's seven hours but I don't go home at that time because my work is not finished. So I can't go home before it's finished plus the staff are normally still here. . I I start to go about fourish. (Female part-time No. 3, Councilco)

The apparent 'need' to work extra hours stemmed from the decision by managers to introduce more flexible schedules for the supervised staff, so that fewer staff worked at any one time, but there were staff working over more of the day and the week. The knock-on effect was to extend the amount of time that supervisors were expected to work, while the number of supervisory staff remained unchanged. A home-care supervisor at Councilco identified a similar trend:

It's Monday to Friday at the moment. That's another thing that may be changing. The home care staff are now going on to rotas which will be from eight in the morning till eight at night. So the organizers are going to have to come on line. (Female part-time No. 7, Councilco)

This apparent understanding by workers of the need to work more hours with no extra pay was achieved largely through the promotion of a view within the organizations we visited that long hours went with the job; they were inevitable: as a female manager at Telecomco commented in relation to her 12-hour day: '... it just goes with the territory' (Female full-time No. 1, Telecomco). In some senses what we were picking up in our research was the playing out of wider trends in the working-time patterns of UK workers, and their expectations about what is required of them by employers in the name of 'flexibility'.

What made both these types of change particularly pronounced is that, as we have mentioned already, organizations were not only asking workers to change when they worked but were also changing and often removing the payments workers received when working 'unsocial hours'. Of course, that these two strategies should be pursued simultaneously is not altogether surprising: quite simply, it is unlikely that any of the organizations we studied would have implemented the changes they made to when staff worked were it not for the treatment of all hours as exactly the same, regardless of when they fell over the day or week. While each organization set about enacting the reduction or withdrawal of unsocial payments in its own way, we found clear evidence of the dismantling of 
long-standard understandings of the relationship between the pay workers receive and when they work. For Everingham (2002) this is just one example of the more widespread 'de-regulation of the workplace'. As she puts it:

The de-regulation of temporal boundaries has. . insidious ways of penetrating the remnants of our familial and communal space. No longer protected by the collectively achieved temporal boundaries of the 8-hour day, workers are exposed directly and individually to the logic of market and its drive for greater and greater productivity. (p. 346)

It was at Mediaco that we found the most extreme case of this: unsocial payments were eliminated by what one worker described as a 'heavy-handed' and wide-ranging restructuring of the employment relationship that involved, inter alia, the loss of overtime and of any extra pay for working on bank holidays. At the other organizations we studied the changes to premia were achieved through less direct and incremental means. Retailco followed others in its sector in abolishing premia for Saturday work in 1995 and setting night rate premia at a lower flat rate level in 1996-7. It did, though, retain the double time premia for Sunday work. Telecomco redefined standard hours for both engineers and clerical staff to extend further into the evening so that no premia were paid for work scheduled between $8 \mathrm{am}$ and 8pm, Monday to Saturday. Bankco initially retained its premia rates when it opened its first call centre in the early 1990 s. It did this as a means of guaranteeing the terms and conditions to workers redeployed from elsewhere in the organization. However, when recruiting new employees to staff its second call centre in 1996, it took the opportunity to reduce premia. By 1999 the differences in terms and conditions at the two call centres were causing industrial relations problems: the reaction of management was to harmonize the premia for all staff at a level between the standard and the second call centre rates.

At the two public sector organizations - Councilco and Healthco - management was constrained by national collective bargaining agreements in a way that its private sector equivalents were not. Rather than directly remove any extra payment for unsocial working, managers at these two organizations were innovative in working out how best to circumvent existing arrangements. Healthco, in common with many NHS trusts, had set up a new staff grade of health-care assistant outside of the Whitley terms and conditions, which structured the hourly rates for nursing staff. For the health-care assistants, while weekend premia were retained at the Whitley level, night premia were not. Also, where weekend or night work was introduced for new groups of staff (for example in the rehabilitation directorate), new contracts were offered at higher basic salary levels to staff but without provision for any additional premia. Temporary and part-time workers were also used to cover the unsocial hours and overtime hours as a means of avoiding having to pay extra to existing full- 
time workers. This policy of circumvention was made possible through the use of the 'bank' (an agency supplying nursing staff, many of whom are also fulltime NHS employees) to cover overtime hours without premia payments. This practice was increasingly being used at Healthco - as part of a national growth in the use of agency staff in the health sector - as permanent staff vacancies were left unfilled. Very similar strategies were adopted at Councilco, including the use of casual, temporary and part-time staff where no premia was paid; for example, all summer seasonal work in the leisure department was now covered this way and the use of these types of workers was increasing in home care to cover the increasing unsocial hours working associated with Care in the Community policies. As with the rehabilitation centre at Healthco, where higher basic salaries were offered in return for commitments to work flexibly and to cover unsocial hours, Councilco set up teams of home-care workers on higher basic salaries but with no premia attached to provide the flexible and 24-hour cover needed to assess patients recently released from hospital.

What this section has revealed are the ways in which the organizations we studied had gone about demanding workers change when they work, with very little regard for the other tasks and commitments workers have outside of their place of work. As a result more and more men and women are finding that their work patterns put them out of synchrony with the temporal order of friends and families (La Valle et al., 2002; Dex, 2003). Our findings also point to the accompanying intensification of activity levels when workers are at work. Together these changes have quite fundamentally restructured the work-effort relationship that characterized many industrialized economies post-World War II. Moreover, both these changes have taken place at the same time as organizations have removed the financial payments received for working in 'free' time. In the next section we turn to the second theme our research explores, that is the gradual blurring of work/non-work time.

\section{Blurring work/non-work time}

At each of our case-study organizations we found that the institutional mechanisms that serve to divide 'standard' work, or public time and 'free', or private time had either been dismantled or eroded. All the organizations had extended operating and/or opening hours, thereby requiring a greater proportion of the workforce to work outside what had previously been regarded as the normal or standard hours. The reduction or elimination of pay premia for 'non-standard' times allowed employers greater freedom to schedule work at no extra financial cost to themselves, although of course, and as we have already suggested, the wider social costs are not inconsequential. It was also clear from what workers said to us that there were work-based costs to moving to work evenings or at weekends. They claimed that having to change when they worked was increas- 
ing the stress they felt under while at work, and was even affecting them during leisure or 'free' hours.

Our research found that, in each organization we visited, managers were justifying and explaining the removal of the temporal boundary in terms of pressures to meet the needs of customers (Fuller and Smith, 1991; Beynon et al., 2002). When pushed in interviews, managers made it clear that they no longer operated the principle, associated with the standard employment relationship, of fitting work, wherever possible, within the confines of standard work hours, even though this principle had by and large underpinned past practice at each of the organizations. In particular we were struck by the rationale offered to us by managers in the public sector. According to this group, the pressures to mimic the private sector in their organization of work and to satisfy the growing audit requirements that they and their departments were under were behind the effort invested in blurring the distinction between social and unsocial working hours (see also, Power, 1997; Probert, 1997; McCammon and Griffin, 2000; Everingham, 2002). As one senior health manager observed in an interview: "if "Retailco" provides a 24-hour service to sell baked beans to customers, then we ought to consider giving patients a 24-hour service.' At all of the organizations we found the notion of protected and standard hours being challenged and evidence of the clear assertion of managerial prerogative in the deployment of labour.

Unlike all the other organizations we visited, on the face of it Bankco was at least trying to observe some notion of standard hours. According to workers and to managers, the organization did try to listen to individuals' preferences over when they wanted to work, although even here some employees claimed that if they asked to change their shifts or to move to part-time hours, the trade-off would be that they would have to work some Saturdays. Nevertheless, it was clear that Bankco was making an effort to identify on a regular basis anyone who needed to change hours because of personal reasons and to do its best to meet those needs.

At the other five case studies, where there was some attempt to respond to the needs or preferences of the individual, it came in the form of informal swap arrangements, often conducted with immediate colleagues. In practice these proved difficult to organize: "if there was somebody willing to swap, but when you are only getting one weekend off every three weeks, who wants to swap their weekend off?' (Male full-time No. 3, Councilco).

Similarly, rights to time off in lieu could also be difficult to exercise because of work pressures, and managers could be required, for example at Retailco, to work a schedule which changed every day and, moreover, 'could be changed at anytime, should someone ring in sick and need cover. So you need to be flexible' (Female full-time No. 1, Retailco). The intrusions into private and family life were clear. Arrangements might have to be changed, appointments cancelled. And yet apparently such has been the pervasiveness of these changes across the 
UK economy that for many workers there was, albeit begrudging, acceptance of the inevitability of unsocial hours working. For example one Bankco employee who had worked weekends reflected: 'we wouldn't mind doing one in four but every weekend is quite hard. .' (Female full-time No. 4, Bankco).

\section{Conclusion}

Many of the assumptions over when staff work and the financial rewards they receive for working unsocial hours no longer hold. The temporal boundary that was erected as part of the emergence of post-World War II industrial relations agreements in the UK has slowly but surely been eroded, as more and more of economic activity takes place outside of the 'standard' working day. While there have always been some jobs that have involved working 'odd' hours, such as the nurses who staffed the accident and emergency wards at the local hospital, the security guards who looked over properties at night, and those in the postal service who sorted through the letters for the morning delivery, recent decades have seen a growth in the number of jobs - and hence the number of workers - who are required to work early in the morning, late at nights, at weekends, or on bank holidays. There is less 'time' that is social, in the sense that it is collective, where it can be expected that almost no one will be performing paid work. It is in this wider context that our research illustrates some of the smaller changes that go to make up these more general trends.

At five of our organizations - the partial exception being Bankco - we found evidence of an intensification of the development of the employer-led workingtime model. In part this was due to managers paying more attention to the economics and organization of time as the basis for competition (Best, 1990). Managers across the organizations appeared to share a common belief that it was now possible to challenge traditional patterns of working-time organization and to use this opportunity to make other changes in the wider employment relationship, for example through increasing the tempo of work or work intensity and to remove the payments associated with unsocial hours. Moreover, for many of the managers this process of change in working-time regimes was only just beginning, with further changes towards flexible scheduling and flexible working hours predicted both by management and by workers. There were clear expectations among managers and the workforce that a process of transition towards an employer-led model of working-time arrangements was underway, and that it was not clear how it could be stopped. It is notable that these expectations were found in large organizations with, for the most part, continuing trade union representation: that is, among those organizations which have up until now been the most likely to be constrained by the 'traditional' UK working-time model. 
The change from this collective and regulated model to a more employerdetermined system of working-time arrangements involved radical changes in Mediaco. The changes in the other organizations were less dramatic but often as far-reaching. At each of the five other organizations - Bankco, Councilco, Healthco, Retailco and Telecomco - the gradual erosion of norms and employment rights for established staff, coupled with the expansion of non-standard employment forms, were behind a fundamental change in how managers and workers talked about and understood 'time', inside and outside of the place of work.

Changes since the end of the 1990s to both labour market conditions and to public policy debate, with the increasing stress on the need to re-establish a better 'work-life balance' might suggest that this form of change may have fallen out of favour. This would be in line with evidence from national surveys on work intensity that suggest that most of the pressure towards intensification came in the early part of the decade - in line with the timing of changes in most of our organizations (Green, 2001). The example of Bankco in our own research certainly suggests that some organizations have had to reassess the viability and sustainability of their new working-time systems and to retreat from the employer-led model if they wish to maintain a motivated and committed workforce. However, problematic human resource outcomes are not necessarily sufficient to induce subsequent change in managerial practice: employers have historically had to be persuaded of the virtues of stable and regulated labour markets, even if they later came to recognize their benefits (Jacoby, 1984), in part because they do not willingly cede their unfettered right to manage. Without new institutional arrangements, in the form of either collective or individual employment rights, it cannot be guaranteed that managers would give back the increased prerogative they have acquired to fix working-time arrangements, and thereby to change the very temporal ordering of the society they are part of. Reduced worker commitment, higher staff turnover rates or even pressure from social commentators and politicians over the sustainability of current work-life arrangements are not necessarily sufficient factors to induce voluntary change in organizations' work practices. Stops and starts may be expected, but in the absence of a renewal of collective regulation in the UK, the workforce needs to look to individual employee rights - associated with the work-life balance debate in the UK and proposals to strengthen working-time regulation in Europe and its implementation in the UK - if the process of transition from the UK system of working-time regulation is not to move the economy towards the employer-led model outlined in Table 1. This model based on the notion of free individual workers, unconstrained either by domestic commitments or by their own requirements for a personal life - is increasingly at odds with the needs of advanced societies as the shift towards dual earner households consolidates (Dex, 2002; Everingham, 2002). Re-regulation 
of the working-time system is essential both to rebalance power relations within the employment relationship and to provide some compatibility between the demands of work and personal and family life. Otherwise, societal sustainability is likely to be further tested by the decisions of individual managers, who are not held accountable for the wider systemic effects of their actions.

\section{Notes}

We are grateful to the Leverhulme Trust who funded the project upon which this research draws. It is based on longitudinal case studies of seven large organizations including one manufacturing company. However, the manufacturing company was not included in this article, as transcripts of the employee interviews had not been completed at the time the article was first drafted. The number of case studies was selected with reference in part to practical issues: namely, the number that we could reasonably expect to include in a longitudinal project. However, the case studies were selected one from each of seven sectors to represent roughly the employment mix of Britain. Within the labour market in which the studies were carried out in the North of England, each organization could be said to be the dominant organization or market leader.

1. Of course, the constructing of temporal boundaries was not gender-neutral: 'men and women experienced this temporal divide differently. . . owing to their different relationship' (Everingham, 2002: 338) to the public and the private spheres.

\section{References}

Adam, B. (1990) Time and Social Theory. Philadelphia: Temple University Press.

Anxo, D. and O'Reilly, J. (2000) 'Working Time Regimes and Transitions in Comparative Perspective', in J. O'Reilly, I. Cebrián and M. Lallement (eds) WorkingTime Changes. Cheltenham: Edward Elgar.

Arrowsmith, J. and Sisson, K. (1999) 'Pay and Working Time: Towards OrganizationBased Systems?', British Journal of Industrial Relations 37: 51-76.

Bacon, N. and Storey, J. (1996) 'Unilever: Flexible Working: Introducing Annualised Hours and 24-hour Working', in J. Storey (ed.) Blackwell Cases in Human Resource and Change Management. Oxford: Blackwell.

Beatson, M. (1995) Labour Market Flexibility. London: Employment Department Research Series No. 48.

Best, M. (1990) The New Competition: Institutions of Industrial Restructuring. Cambridge: Polity Press.

Beynon, H., Grimshaw, D., Rubery, J. and Ward, K. (2002) Managing Employment Change: the New Realities of Work. Oxford: Oxford University Press.

Blyton, P. (1992) 'Learning From Each Other: the Shorter Working Week Campaigns in Germany and Britain', Economic and Industrial Democracy 13: 417-30.

Blyton, P. (1994) 'Working Hours', in K. Sisson (ed.) Personnel Management. Oxford: Blackwell. 
Blyton, P. (1995) 'United Kingdom: the Case of the Metal Manufacturing Industry', in OECD Flexible Working Time. Paris: OECD.

Bosch, G. (1999) 'Working Time: Tendencies and Emerging Issues', International Labour Review 138: 131-50.

Bosch, G., Dawkins, P. and Michon, F. (1994) Times Are Changing: Working Time in 14 Industrialised Countries. Geneva: International Institute for Labour Studies.

Boulin, J. Y. and Hoffman, R. (eds) (1999) New Paths in Working Time Policy. Brussels: European Trade Union Institute.

Casey, B., Metcalf, A. and Millward, N. (1997) Employers' Use of Flexible Labour. London: Policy Studies Institute.

Clark-Campbell, S. (2000) 'Work, Family, Border Thesis: a New Theory for Work-Life Balance', Human Relations 54: 747-61.

Curson, C. (1986) Flexible Patterns of Work. London: Institute of Personnel Development

Daune-Richard, A. M. (1998) 'How Does the "Societal Effect" Shape the Use of PartTime Work in France, Sweden and the UK?', in J. O'Reilly and C. Fagan (eds) Parttime Prospects; Part-Time Employment in Europe, North America and the Pacific Rim. London: Routledge.

Dex, S. (2003) Families and Work in the Twenty-First Century. Bristol: Policy Press.

Donaldson, M. (1996) Taking Our Time: Remaking the Temporal Order. Nedlands: University of Western Australian Press.

Everingham, C. (2002) 'Engendered Time: Gender Equity and Discourses of Workplace Flexibility', Time \& Society 11(2/3): 335-51.

Fagan, C. (2001) 'The Temporal Reorganization of Employment and the Household Rhythm of Work Schedules', American Behavioural Scientist 44: 1199-1212.

Fuller, L. and Smith, V. (1991) 'Customers' Reports: Management by Customers in a Changing Economy', Work, Employment and Society 5: 1-16.

Gall, G. (1996) 'All Year Round: the Growth of Annual Hours in Britain', Personnel Review 25: 35-52.

Glucksmann, M. (1998) 'What a Difference a Day Makes: a Theoretical and Historical Explanation of Temporality and Gender', Sociology 32: 239-58.

Green, F. (2001) 'It's Been a Hard Day's Night: the Concentration and Intensification of Work in Late Twentieth-Century Britain', British Journal of Industrial Relations 39: 53-80.

Harkness, S. (1999) 'Working 9 to 5'? , in P. Gregg and J. Wadsworth (eds) The State of Working Britain. Manchester: Manchester University Press.

Harvey, M. (1999) 'Economies of Time: a Framework for Analysing the Restructuring of Employment Relations', in A. Felstead and N. Jewson (eds) Global Trends in Flexible Labour. Basingstoke: Macmillan.

Heyes, J. (1997) 'Annualised Hours and the "Knock": the Organisation of Working Time in a Chemicals Plant', Work, Employment and Society 11: 65-81.

Hinrichs, K., Roche, W. and Sirianni, C. (eds) (1991) Working Time in Transition: the Political Economy of Working Hours and Industrial Relations. Philadelphia: Temple University Press.

Hochschild, A. R. (1997) The Time Bind: When Work Becomes Home and Home becomes Work. New York: Metropolitan Books.

Jacoby, S. (1984) 'The Development of Internal Labour Markets in American Manu- 
facturing Firms', in P. Osterman (ed.) Internal Labour Markets. Cambridge, MA: MIT Press.

Kalleberg, A. and Epstein, C. F. (2001) 'Introduction: Temporal Dimensions of Employment Relations', American Behavioural Scientist 44: 1064-75.

Kodz, J., Kersley, B. and Strebler, M. (1998) Breaking the Long Hours Culture. Brighton: Institute for Employment Studies.

La Valle, I., Arthur, S., Millward, C. and Scott J. (2002) Happy Families? Atypical Work and Its Influence on Family Life. Bristol: Policy Press.

Lehndorff, S. (1998) 'From "Collective" to "Individual" Reductions in Working Time? Trends and Experience with Working Time in the European Union', Transfer 4: 598-620.

Lewis, S. (1997). 'Family Friendly Employment Policies: a Route to Changing Organizational Culture, or Playing About at the Margins?', Gender, Work and Organization 4: $13-23$.

McCammon, A. and Griffin, L. J. (2000) 'Workers and Their Customers and Clients', Work and Occupation 27: 278-94.

Maier, F. (1994) 'Institutional Regimes of Part-time Working', in G. Schmid (ed.) Labour Market Institutions in Europe. New York: M. E. Sharpe.

Neathey, F. and Hurstfield, J. (1996) Flexibility in Practice: Women's Employment and Pay in Retail and Finance. Manchester: EOC.

OECD (1995) Flexible Working Time. Paris: OECD.

O'Reilly, J. and Fagan, C. (eds) (1998) Part-time Prospects; Part-time Employment in Europe, North America and the Pacific Rim. London: Routledge.

Power, M. (1997) The Audit Society: Rituals of Verification. Oxford: Oxford University Press.

Probert, B. (1997) 'Job Sharing: A Work in Progress', The Australian, 29 January.

Rubery, J. (1987) 'Flexibility of Labour Costs in Non-union Firms', in R. Tarling (ed.) Flexibility and the Labour Market. London: Academic Press.

Rubery, J. (1998a) 'Working Time in the UK', Transfer 4: 657-77.

Rubery, J. (1998b) 'Part-Time Work: a Threat to Labour Standards', in J. O'Reilly and C. Fagan (eds) Part-time Prospects; Part-time Employment in Europe, North America and the Pacific Rim. London: Routledge.

Rubery, J. and Horrell, S. (1993) 'The New Competition and Working Time', Human Resource Management Journal 3: 1-13.

Rubery, J., Smith, M. and Fagan, C. (1998) 'National Working Time Regimes and Equal Opportunities', Feminist Economics 4: 71-102.

Simpson, R. (1997) 'Presenteeism, Power and Organisational Change: Long Hours as a Career Barrier and the Impact on the Working Lives of Women Managers', British Journal of Management 9: 37-52.

Supiot, A. (2001) Beyond Employment: Changes in Work and the Future of Labour Law in Europe. Oxford: Oxford University Press.

Thompson, E. P. (1967) 'Time, Work Discipline and Industrial Capitalism', Past and Present December: 56-97.

Tietze, S. and Musson, G. (2002) 'When "Work" Meets "Home": Temporal Flexibility as Lived Experience', Time \& Society 11(2/3): 315-34.

White, M. (1980) Shorter Working Time. London: Policy Studies Institute. 


\section{Appendix - Introducing the case-study organizations}

- 'Bankco' is a major clearing bank in the UK employing around 3,700 staff. It has a reputation for introducing new financial products in the sector and has been quick to exploit the new technologies in information and telecommunications systems;

- 'Councilco' is a large urban city council. It has a total workforce of around 25,000. Operations stretch across a range of activities, including school and civic catering, community care, environmental health and indoor and outdoor leisure services;

- 'Healthco' is a large city centre NHS Trust, which combines the provision of acute medical care with teaching and research activities and often acts as a tertiary referral site. It employs a total of around 5,000 staff;

- 'Mediaco' consists of two companies in the newspaper industry - the editorial and advertising offices of a local newspaper, together with the nearby printworks. The newspaper offices are wholly owned by a large national media group; the printworks operate under joint ownership with this and another national media group. Around $x$ employees work at the newspaper offices and $y$ at the printworks;

- 'Retailco' is one of the leading food retail chains in the UK, supplying a range of around 40,000 products. With a total workforce of around 155,000 , predominantly part time, it is one of the largest private sector employers in the UK;

- 'Telecomco' is one of the largest providers of telecommunications services in the UK, providing a number of business and customer services, in addition to maintenance of the telephone network. The total workforce stands at around 130,000. Development of mobile telephone services and the internet has recently contributed to high profit margins.

Note: all employment data refer to 1998.

JILL RUBERY is Professor of Comparative Employment Systems, Manchester Business School at the University of Manchester. She is coauthor of Managing Employment Change (with Huw Beynon, Damian Grimshaw and Kevin Ward, Oxford University Press, 2002), co-author of The Organization of Employment: An International Perspective (with Damian Grimshaw, Palgrave Macmillan, 2002) and co-editor of Fragmenting Work (with Mick Marchington, Damian Grimshaw and Hugh Willmott, Oxford University Press, 2004). ADDRESS: Manchester Business School, University of Manchester, Oxford Road, Manchester, M13 9PL, UK.

[email: jill.rubery@manchester.ac.uk]

KEVIN WARD is Senior Lecturer in Geography, the School of Environment and Development at the University of Manchester, UK. He is co-author of Spaces of Work: Global Capitalism and the Geographies of Labour (SAGE, 2003), Urban Sociology, Capitalism and Modernity (Macmillan, 2003) and Managing Employment Change: the New Realities of Work (Oxford University Press, 2002) and co-editor of City of Revolution: Restructuring Manchester (Manchester University Press, 2002) and over 30 articles and book chapters on state reorganization, the 
politics of urban development, employment change and labour market restructuring. ADDRESS: School of Environment and Development, University of Manchester, Oxford Road, Manchester, M13 9PL, UK.

[email: k.g.ward@manchester.ac.uk]

DAMIAN GRIMSHAW is Senior Lecturer in Employment Studies, Manchester Business School at the University of Manchester. He is coauthor of Managing Employment Change (with Huw Beynon, Jill Rubery and Kevin Ward, Oxford University Press, 2002), co-author of The Organization of Employment; an International Perspective (with Jill Rubery, Palgrave Macmillan, 2002) and co-editor of Fragmenting Work (with Mick Marchington, Jill Rubery and Hugh Willmott, Oxford University Press, 2004). ADDRESS: Manchester Business School, University of Manchester, Oxford Road, Manchester, M13 9PL, UK.

[email: d.p.grimshaw@mbs.ac.uk]

HUW BENYON is Professor in the School of Social Sciences, Cardiff University, UK. He is author of a number of books including Working for Ford (Penguin, 1973), Living with Capitalism (with Theo Nichols, Routledge, 1979) and Managing Employment Change: the New Realities of Work (with Damian Grimshaw, Jill Rubery and Kevin Ward, Oxford University Press 2002) and numerous articles on labour organization, 'globalization', new forms of business and environmental questions. ADDRESS: Cardiff University School of Social Sciences, Glamorgan Building, King Edward VII Avenue, Cardiff CF10 3WT, UK.

[email: Beynon@cardiff.ac.uk] 